\section{ON A COLLECTION OF BUTTERFLIES FROM PADDY FIELD ECOSYSTEM OF PALAKKAD DISTRICT, KERALA}

\author{
V.P. Soniya ${ }^{1}$ and Muhamed Jafer Palot ${ }^{2}$ \\ ${ }^{1}$ Zoological Survey of India, Freshwater Biological Station, Ashok \\ Nagar, Hyderabad, Andhra Pradesh 500020 India. \\ ${ }^{2}$ Zoological Survey of India, Western Ghats Field Research Station, \\ Kozhikode, Kerala 673002, India.
}

The district of Palakkad is popularly known as the rice bowl of Kerala. The present study area Nanniode $\left(10^{\circ} 42^{\prime} \mathrm{N}\right.$ and $\left.76^{\circ} 47^{\prime} \mathrm{E}\right)$ is a small village in Perumatty Panchayat of Chittur Taluk that lies about $25 \mathrm{~km}$ south east of Palakkad Town. The area supports about 60acres of extensive paddy cultivation. Traditionally two crops are taken in a year (June to September and October to March). Due to the proximity of Palakkad gap of Western Ghats, the area experiences an oppressive hot season during April and May and plentiful fairly well seasonal rainfall. The rainfall is mainly in south-west monsoon during June to September and sparingly in north-east monsoon. Temperature varies from $19^{\circ}$ $42^{\circ} \mathrm{C}$. The area is well irrigated with artificial irrigation canals, tanks, etc.

The present report is based on a collection made during AugustSeptember, 1999 (harvesting stage of paddy) and December 1999 to January 2000 (early stage) from paddy fields and associated area of the village. Only adults were collected using insect nets and later identified with the help of field guides (Wynter-Blyth, 1957; Gay et al., 1992).

A total of 43 species of butterflies belonging to five families were recovered from the paddy fields of Nanniode Village. The family Nymphalidae dominated with 16 species followed by Papilionidae (8), Pieridae and Lycaenidae (7 each) and Hesperiidae (5). Spialia galba and Barbo cinnara dominated during the early stage of paddy. Lesser number of species were recorded in the harvesting stage. Junonia lemonias, Leptosoa nina, Catopsilia pomona, Eurema hecabe, Jamides celeno and Melanitis leda were found throughout the study. Nomenclature and systematics followed are after Gaonkar (1996). The systematic list is given in Table 1.

\section{Acknowledgements}

We are grateful to the Dr J.R.B. Alfred, Director, Zoological Survey of India, Calcutta for facilities and encouragement.

References

Gaonkar, H. (1996). Butterflies of the Western Ghats. A Biodiversity assessment of threatened mountain system. Report to the Centre for Ecological Science, Indian Institute of Science, Bangalore.

Gay, T., I.D. Kehimkar and J.D. Punetha (1992). Common Butterflies of India. World Wide Fund for Nature - India, Bombay.

Wynter-Blyth, M.A. (1957). Butterflies of Indian Region. Bombay Natural History Society, Bombay.

Table 1. List of butterflies of Nanniode, Kerala

\begin{tabular}{ll}
\hline Scientific Name & Common Name \\
\hline Papilionidae & \\
Graphium agamemnon menides (Felder \& Felder) & Tailed Jay \\
Graphium sarpedon teredon (Felder \& Felder) & Common Blue Bottle \\
Pachliopta aristolochiae (Fabricius) & Common Rose \\
Pachliopta demoleus demoleus Linnaeus & Lime Butterfly \\
Pachliopta hector (Linnaeus) & Crimson Rose \\
Pachliopta polytes polytes (Linnaeus) & Common Mormon \\
Pachliopta polymnestor polymnestor Cramer & Blue Mormon \\
Troides minos Cramer & Southern Birwing
\end{tabular}

Pieridae

Catopsilia pomona (Fabricius)

Catopsilia pyranthe (Linnaeus)

Delias eucharis(Drury)

Eurema blanda silhetana (Wallace)

Eurema hecabe simultata (Moore)

Leptosia nina nina (Fabricius)

Parenonia valeria hippia (Febricius)

Nyphalidae

Acraea violae (Fabricius)

Ariadne merione merione Cramer

Danaus chrysippus chrysippus (Linnaeus)

Danaus genutia genutia (Cramer)

Euploea core core (Cramer)

Euthalia aconthea meridionalis Frushstorfer

Junonia almana almana (Linnaeus)

Junonia atlites atlites (Linnaeus)

Junonia iphita pluvialis Fruhstorfer

Junonia lemonias (Linnaeus)

Melanitis leda lada (Drury)

Mucalesis mineus polydecta (Cramer)

Mucalesis perseus typhlus Fruhstorfer

Orsotrioena medus mandata ( Moore)

Phalanta phalanta phalanta (Drury)

Tirumala limniace exoticus Gmelin

Lycaenidae

Castalius rosimon rosimon (Fabricius)

Euchrysops cnejus cnejus (Fabricius)

Everes lacturnus syntala Cantille

Freyeria trochylus putli (Kollar)

Jamides celeno aelianus (Farbricius)

Pseudozizeeria maha ossa (Seinhoe)

Rathinda amor (Fabricius)

Common Emigrant
Mottled Emigrant
Common Jezebel
Three-spot Grass Yellow
Common Grass Yellow
Psyche
Common Wanderer

Tawny Coaster

Common Coastor

Plain or Common Tiger

Striped Tiger

Common Crow

Common Baron

Peacock Pansy

Grey Pansy

Chocolate Pansy

Lemon Pansy

Common Evening Brown

Dark-brand Bush Brown

Common Bush Brown

Nigger

Leopard Butterfly

Blue Tiger

Common Pierrot

Gram Blue

Indian Cupid

Grass Jewel

Common Cerulean

Pale grass Blue

Monkey Puzzle

Hesperiidae

Ampitta discorides discorides (Fabricius)

Barbo cinnara (Wallace)

Pelopidas mathias mathias (Fabricius)

Spialia galba galba (Fabricius)

Suastus gremius gremius (Fabricius)
The Bush Hopper
The Rice Swift
The Small Branded Swift
The Rice Skipper
The Indian Palm Bob 